\title{
Hubungan Sikap Dan Pengetahuan Ibu Hamil Dalam Perawatan Keputihan Di Puskesmas Gedong Tataan
}

\section{The Relationship between attitudes and Knowledge Of Pregnant Women In The Treatment Of Vaginal Discharge at The Gedong Tataan Health Center}

\author{
Desi Ari Madiyanti \\ UniversitasMuhammadiyah Pringsewu \\ e-mail: arimadiyantidesi@yahoo.com
}

\begin{abstract}
ABSTRAK
Keputihan pada ibu hamil merupakan hal yang fisiologi, namun bila tidak dimanajemen dengan baik dapat mengakibatkan keputihan patologis. Pengetahuan dan sikap memiliki peran penting dalam mencegah keputihan selama kehamilan.Tujuan penelitian ini adalah mengetahui hubungan Pengetahuan dan Sikap Ibu hamil dalam Perawatan Keputihan di Puskesmas Gedong Tataan tahun 2019.Desain penelitian ini adalah observasional analitik dengan pendekatan cross sectional. Subjek penelitian ini adalah ibu hamil yang mengalami keputihan ketika penilitian berlangsung dengan jumlah 38 orang yang dengan teknik simple random sampling. Penelitian ini dilakukan pada bulan Juli 2019. Pengumpulan data menggunakan data primer yaitu dengan cara membagikan lembar kuesioner yang telah di uji validitas dan reliabilitas. Uji yang digunakan dalam analisis ini adalah uji chai square. Hasil : Ada hubungan antara pengetahuan dengan perawatan keputihan di Puskesmas Gedong Tataan tahun 2019. Berdasarkan nilai OR didapatkan 25,667, yang berarti ibu hamil yang memiliki pengetahuan kurang berisiko 25 kali untuk memiliki perawatan buruk bila dibandingkan dengan ibu yang memiliki pengetahuan baik. Ada hubungan antara sikap ibu hamil dengan perawatan keputihan di Puskesmas Gedong Tataan tahun 2019. Berdasarkan nilai OR didapatkan 17,5, yang berarti ibu hamil yang memiliki sikap negative berisiko 17 kali untuk memiliki perawatan buruk bila dibandingkan dengan ibu yang memiliki sikap yang positif. Kesimpulan: Pengetahuan dan sikap berhubungan dengan Perawatan Keputihan di Puskesmas Gedong Tataan tahun 2019
\end{abstract}

Kata Kunci: Pengetahuan, Perawatan, Keputihan, Sikap

\begin{abstract}
Leucorrhoea in pregnant women is physiological, but if not managed properly can lead to pathological vaginal discharge. Knowledge and attitude have an important role in preventing vaginal discharge during pregnancy. The purpose of this study was to determine the relationship of Knowledge and Attitudes of Pregnant Women in Leucorrhoea Care at the Gedong Tataan Health Center in 2019. The design of this study was observational analytic with cross sectional approach. The subjects of this study were pregnant women who experienced vaginal discharge when the study took place with 38 people using simple random sampling technique. This research was conducted in July 2019. Data collection uses primary data by distributing questionnaire sheets that have been tested for validity and reliability. The test used in this analysis is the Chai Square test. Results: There is a relationship between knowledge and leucorrhoea care at Gedong Tataan Health Center in 2019. Based on OR values obtained 25.667, which means pregnant women who have less risk of knowledge 25 times to have bad care when compared to mothers who have good knowledge. There is a relationship between the attitude of pregnant women with vaginal discharge in Gedong Tataan Health Center in 2019. Based on OR values obtained 17.5, which means pregnant women who have a negative attitude risk 17 times to have bad care when compared with mothers who have positive attitudes. Conclusion: Knowledge and attitude related to Leucorrhoea Treatment at the 2019 Gedong Tataan Health Center
\end{abstract}

Keywords: Knowledge, Leucorrhoea Treatment, Attitudes 


\section{PENDAHULUAN}

Kehamilan adalah suatu kondis yang melibatkan berbagai perubahan didalam tubuh. Perubahan yang sering kali terjadi pada ibu hamil diantaranya adalah perubahan fisik dan psikologis seperti pembesaran payudara, sering buang air kecil, konstipasi, mual, muntah, merasa lelah, sakit kepala, pusing, emosional, peningkatan berat badan, termasuk juga perubahan di vagina seperti keputihan ${ }^{1}$. Pada masa kehamilan Peningkatan kadar hormon esterogen menyebabkan vagina cenderung mengeluarkan lebih banyak cairan, peningkatan kadar air pada dinding vagina ini yang disebut sebagai keputihan pada ibu hamil dan keputihan yang terjadi karena hal tersebut masih tergolong normal ${ }^{2}$. Word Health Organization (WHO) yang menyatakan bahwa yang menjadi masalah kesehatan wanita hamil yang mengalami keputihan sebesar $31,6 \%$ yang disebabkan oleh jamur Candidia Albieans dan negara Indonesia adalah daerah yang beriklim teropis sehingga jamur mudah sekali berkembang oleh karena itu, sekitar 90\% wanita berpotensi mengalami keputihan terutama ibu hamil rentan mengalami keputihan ${ }^{4}$.

Keputihan saat hamil memang harus diatasi sejak dini, sebab bila tidak kondisi akan menimbulkan gejala yang semakin berbahaya. Jika sudah kronis dan berlangsung dalam waktu lama keputihan akan semakin sulit diobati. Jika dibiarkan saja keputihan akan merembet pada organ rahim dan menuju kesaluran indung telur dan mengakibatkan kemandulan dan kehamilan diluar rahim ${ }^{5}$. Hal ini sejalan dengan penelitian yang dilakukan oleh Kusuma yang menyatakan bahwa sebagian informan mengatakan pernah mengalami keputihan pada saat hamil. Keputihan yang dialami terus menerus pada saat hamil jika tidak ditangani dengan baik akan mengakibatkan infeksi pada vagina serta dapat mengganggu perkembangan janin bahkan abortus pada ibu hamil ${ }^{6}$. Perempuan yang mengalami keputihan masih menyimpan rapat - rapat keluhan yang dialaminya, karena malu untuk memeriksakan diri sehingga terkadang keputihan yang dialami oleh wanita sudah menjadi parah. Kurangnya perilaku dalam menjaga kebersihan organ kewanitaan juga merupakan faktor yang bisa mengakibatkan keputihan, sehingga bakteri dan jamur akan tumbuh dengan cepat pada tempat kotor dan lembab dapat menimbulkan infeksi ${ }^{7}$. Pengetahuan dan sikap merupakan domain yang ada dalam membentuk perilaku seseorang ${ }^{8}$. Adanya hubungan yang sangat signifikan antara pengetahuan vulva hygiene dengan kejadian keputihan ${ }^{9}$.

Menurut penelitian yang dilakukan oleh Musdhalifah menyatakan bahwa ibu hamil yang memiliki pengetahuan tentang cara pengobatan atau penanganan keputihan mayoritas ibu hamil tidak tahu $(66,67 \%)$, hal 
ini disebabkan karena kurangnya informasi yang diperoleh responden tentang pengobatan keputihan dan tidak adanya kesadaran individual untuk mencari informasi dan mengetahui lebih jauh tentang pengobatan atau penanganan keputihan ${ }^{10}$. Meskipun banyak ibu hamil yang mengalami keputihan namun mereka menganggap hal tersebut sebagai sesuatu yang normal, sehingga menyebabkan persepsi yang kurang tepat terhadap keputihan. Hal ini sejalan dengan penelitian yang dilakukan oleh Natika dalam penelitiannya menyatakan bahwa sikap ibu hamil dalam menangani keputihan memiliki sikap negatif $(52,5 \%)$, menunjukkan bahwa sebagian besar ibu hamil belum mengetahui tentang cara menangani keputihan yang baik selama hamil ${ }^{12}$. Hal ini sejalan dengan penelitian yang dilakukan oleh Usman yang menyatakan bahwa perilaku hygiene organ genetalia eksterna pada ibu hamil dari 23 responden, 14 responden $(60,9 \%)$ memiliki sikap yang buruk dan mengalami keputihan patologis. Sehingga terdapat hubungan antara sikap hygiene organ genetalia dengan kejadian keputihan ${ }^{13}$.

Persepsi dan sikap yang tidak tepat akan memperlemah motivasi seseorang untuk berprilaku sehat dalam upaya mencegahan dan penanganan keputihan, hal ini sejalan dengan penelitian yang dilakukan oleh Sukamto yang mengatakan adanya hubungan yang signifikan antara sikap dan prilaku wanita dalam upaya pencegahan keputihan ${ }^{11}$. Berdasarkan hasil prasurvey yang dilakukan dengan cara wawancara secara langsung oleh peneliti pada 10 ibu hamil didapatkan data 2 memiliki perilaku baik dan 8 memiliki perilaku buruk, dari 10 orang ibu hamil semua mengalami keputihan. selain itu 8 ibu hamil yang mengalami keputihan mengatakan bahwa tidak melakukan perawatan apapun dikarenakan mereka tidak tahu cara merawat dan menanganinya serta menganggap itu adalah hal yang biasa dan dapat sembuh dengan sendirinya. Penelitian ini bertujuan untuk mengetahui hubungan Pengetahuan dan Sikap Ibu hamil dalam Perawatan Keputihan di Puskesmas Gedong Tataan tahun 2019”

\section{METODE}

Desain penelitian ini adalah observasional analitik dengan pendekatan cross sectional. Subjek penelitian ini adalah ibu hamil yang mengalami keputihan ketika penelitian berlangsung dengan jumlah 38 orang yang dengan teknik simple random sampling. Uji yang digunakan dalam analisis ini adalah $u j i$ chai square.

\section{HASIL}

Analisis Univariat dilakukan terhadap tiap variable penelitian. Pada analisis ini akan menghasilkan distribusi frekuensi dari tiap variabel. Dalam penelitian ini analisis yang dilakukan untuk mengetahui distribusi dan 
presentase dari responden tentang pengetahuan dan sikap ibu hamil dengan perawatan keputihan yang dapat dilihat pada data lampiran dan disajikan dalam bentuk tabel dan teks.

Tabel 1

Distribusi Frekuensi Pengetahuan Ibu Hamil Yang Mengalami Keputihan Di Puskesmas Gedong Tataan

\begin{tabular}{lcc}
\hline \multicolumn{1}{c}{ Pengetahuan } & N & \% \\
\hline Baik & 24 & 63,2 \\
Kurang & 14 & 36,8 \\
\hline \multicolumn{1}{c}{ Total } & 38 & 100 \\
\hline
\end{tabular}

Berdasarkan tabel 1 diketahui bahwa, sebagian besar ibu hamil dengan pengetahuan baik ,2\% ( 24) responden dan $36,8 \%$ ( 14) responden dengan pengetahuan kurang. Pengetahuan yang baik sangat mempengaruhi prilaku seseorang dalam menjaga kesehatan terutama ibu hamil, terutama dalam melakukan perawatan keputihan yang terjadi selama kehamilannya.

Tabel 2

Distribusi Frekuensi Sikap Ibu Hamil Yang Mengalami Keputihan Di Puskesmas Gedung Tataan

\begin{tabular}{lcc}
\hline \multicolumn{1}{c}{ Sikap } & n & \% \\
\hline Positif & 25 & 65,8 \\
Negatif & 13 & 34,2 \\
\hline \multicolumn{1}{c}{ Total } & 38 & 100
\end{tabular}

Berdasarkan tabel 2 diketahui bahwa, sebagian besar ibu hamil yang mengalami keputihan memiliki sikap positif $65,8 \%,(25)$ responden sedangkan $34,2 \%$ (13) responden

\section{AnalisisBivariat}

Analisa ini digunakan untuk melihat Hubungan antara pengetahuan dan sikap ibu hamil terhadap perawatan keputihan Di Puskesmas Gedung Tataan Kabupaten Pesawaran Lampung Tahun 2019. 
Tabel 4

HubunganTingkat Pengetahuan Ibu Hamil Dengan Perawatan Keputihan Di Puskesmas Gedong Tataan

\begin{tabular}{|c|c|c|c|c|c|c|c|c|}
\hline \multirow[t]{3}{*}{ Pengetahuan } & \multicolumn{4}{|c|}{ Perawatan } & & & \multirow[t]{3}{*}{ P-value } & \multirow[t]{3}{*}{ OR } \\
\hline & \multicolumn{2}{|c|}{ Baik } & \multicolumn{2}{|c|}{ Buruk } & \multicolumn{2}{|c|}{ Total } & & \\
\hline & $\mathbf{N}$ & $\%$ & $\mathbf{N}$ & $\%$ & $\mathbf{N}$ & $\%$ & & \\
\hline Baik & 21 & 87,5 & 3 & 12,5 & 24 & 100 & $<0,001$ & 25,667 \\
\hline Kurang & 3 & 21,4 & 11 & 78,6 & 14 & 100 & & $(4,421-48,996)$ \\
\hline Total & 24 & 63,2 & 14 & 36,8 & 38 & & & \\
\hline
\end{tabular}

Berdasarkan tabel 4 diinformasikan bahwa dari 24 responden yang memiliki pengetahuan baik, terdapat $3(12,5 \%)$ yang memiliki perawatan buruk. Dari 14 responden yang memiliki pengetahuan kurang, terdapat tiga kali lipat 11 $(78,6 \%)$ responden yang memiliki perawatan buruk. Hasil analisis lebih lanjut didapatkan $\rho$ value $<0,001<\alpha=$ 0,05 sehingga hipotesis alternative diterima dan hipotesis nul ditolak. Hal ini berarti Ada hubungan antara pengetahuan dengan perawatan keputihan di Puskesmas Gedong Tataan tahun 2019. Berdasarkan nilai OR didapatkan 25,667, yang berarti ibu hamil yang memiliki pengetahuan kurang berisiko 25 kali untuk memiliki perawatan buruk bila dibandingkan dengan ibu yang memiliki pengetahuan baik.

Tabel 5

Hubungan Sikap Ibu Hamil Dengan Perawatan Keputihan Di Puskesmas Gedung Tataan

\begin{tabular}{|c|c|c|c|c|c|c|c|c|}
\hline \multirow[t]{3}{*}{ Sikap } & \multicolumn{4}{|c|}{ Perawatan } & & & \multirow{3}{*}{$\begin{array}{c}\mathbf{P} \\
\text { value }\end{array}$} & \multirow[t]{3}{*}{ OR } \\
\hline & \multicolumn{2}{|c|}{ Baik } & \multicolumn{2}{|c|}{ Buruk } & \multicolumn{2}{|c|}{ Total } & & \\
\hline & $\mathbf{N}$ & $\%$ & $\mathbf{N}$ & $\%$ & $\mathbf{N}$ & $\%$ & & \\
\hline Positif & 21 & 84,0 & 4 & 16,0 & 25 & 100 & $<0,001$ & $17,5 \quad(3,276-$ \\
\hline Negatif & 3 & 23,1 & 10 & 76,9 & 13 & 100 & & $23,493)$ \\
\hline Total & 24 & 63,2 & 14 & 36,8 & 38 & & & \\
\hline
\end{tabular}

Berdasarkan tabel 5 diinformasikan bahwa dari 25 responden yang memiliki sikap positif, terdapat $4(16,0 \%)$ yang memiliki perawatan buruk. Dari 13 responden yang memiliki sikap negatif, terdapat tiga kali lipat
$10(76,9 \%)$ responden yang memiliki perawatan buruk. Hasil analisis lebih lanjut didapatkan $\rho$ value $<0,001<\alpha=0,05$ sehingga hipotesis alternative diterima dan hipotesis nul ditolak. Hal ini berarti Ada 
hubungan antara sikap ibu hamil dengan perawatan keputihan. Berdasarkan nilai OR didapatkan 17,5, yang berarti ibu hamil yang memiliki sikap negative berisiko 17 kali untuk memiliki perawatan buruk bila dibandingkan dengan ibu yang memiliki sikap yang positif.

\section{PEMBAHASAN}

\section{Pengetahuan Ibu Hamil Yang Mengalami Keputihan Di Puskesmas Gedong Tataan}

Berdasarkan hasil penelitian distribusi frekuensi pengetahuan ibu hamil yang megalami kepuihan dapat diketahui bahwa dari 38 responden didapatkan hasil responden yang berpengetahuan baik yaitu sebanyak 24 responden $(63,2 \%)$, sedangkan responden yang berpengetahuan kurang baik berjumlah 8 responden $(27,8 \%)$.

Pengetahuan (knowledge) adalah hasil tahu dari manusia, yang sekedar menjawab pertanyaan. Pengetahuan dapat salah atau keliru, karena bila pengetahuan ternyata salah atau keliru, tidak dapat dianggap sebagai pengetahuan ${ }^{8}$.

Hasil penelitian ini sejalan dengan Yanti dan Sulistianingsih hasil penelitian menunjukan bahwa perempuan yang memiliki pengetahuan kurang $(85,4 \%)$, dua kali lebih besar dari perempuan yang memiliki pengetahuan baik sebanyak $(56,5 \%)^{14}$. Berdasarkan hal tersebut maka peneliti menarik kesimpulan bahwa pengetahuan dapat berhubungan dengan kejadian flour albus.

\section{Sikap Ibu Hamil terhadap perawatan Yang Mengalami Keputihan Di Puskesmas Gedung Tataan}

Berdasarkan hasil penelitian distribusi frekuensi tentang sikap ibu hamil tentang perawatan keputihan dapat diketahui bahwa dari 38 responden didapatkan hasil yang perawatan keputihan dalam katagori baik yaitu sebanyak 25 responden $(65,8 \%)$ sedangkan yang perawatan keputihan dalam katagori kurang baik yaitu sebanyak 13 responden $(34,2 \%)$.

Sikap juga dipengaruhi oleh tingkat pengetahuan, jika pengetahuan seseorang itu baik maka dia akan mengetahui bagaimana cara bersikap yang positif ataau negatif. Komponen afektif merupakan perasaan seseorang yang menyangkut aspek emosional terhadap suatu objek sikap. Komponen ini merupakan perasaan individu terhadap objek sikap dan menyangkut masalah emosi dari diri seseorang ${ }^{15}$.

Menurut Allport mengatakan bahwa sikap terdiri dari 3 komponen yaitu kepercayaan (keyakinan), ide dan konsep terhadap suatu objek artinya bagaimana pendapat atau keyakinan seeorang terhadap objek. Komponen kedua evaluasi emosional dan komponen ketiga kecenderungan untuk berpihak. Sikap juga terdiri dari tingkatan yaitu: menerima, merespon, menghargai dan 
bertanggung jawab. Sikap juga dapat bersifat positif yaitu kecenderungan untuk menyenangi, menyetujui terhadap suatu objek tertentu atau sebaliknya terhadap sikap negatif, dengan menjauhi, membenci atau tidak menyukai suatu objek tertentu, hal ini sesuai dengan hasil penelitian dari Natika yang mengatakan bahwa sebagian besar (50\%) memiliki sifat yang positif terhadap perawatan keputihan pada saat kehamilan ${ }^{12}$.

Novita, dalam penelitian mengatakan bahwa yang sebagian besar responden memiliki sikap positif $(62,8 \%)$, perbedaan ini dapat disebabkan karena perbedaan karakteristik responden yang digunakan dalam penelitian Novita, sebagai respondennya adalah remaja yang usianya lebih muda banyak menyerap hal-hal yang baru, mencari sumber informasi tentang kesehatan, belajar memfungsikan, menguasai secara maksimal fungsi fisik dan psikis.

\section{Perawatan KeputihanPadaIbu Hamil Di Puskesmas Gedong Tataan}

Berdasarkan hasil penelitian distribusi frekuensi perawatan keputihan dapat diketahui bahwa sebagian besar ibu hamil yang mengalami keputihan melakukan perawatan dengan baik 63,2\%, (24) sedangkan $36,8 \%$ (14) ibu hamil yang mengalami keputihan melakukan perawatan keputihan dengan buruk
Keputihan saat hamil memang harus diatasi sejak dini. Jika sudah kronis dan berlangsung dalam waktu lama keputihan akan semakin sulit diobati. Selain itu keputihan juga dapat menyebabkan penyakit kanker leher rahim sehingga harus diwaspadai sejak dini ${ }^{16}$.

Hasil penelitian ini tidak sejalan dengan Fitrianingsih, yang berjudul hubungan tingkat pengetahuan, sikap dan perilaku pemeliharaan organ reproduksi dengan risiko kejadian keputihan pada siswi kelas X SMA Negeri 1 Wonosari Kabupaten Klaten. Hasil penelitian menunjukan perilaku perawatan organ reproduksi didominasi katagori baik yaitu 66 responden (56,4\%) Menurut pendapat peneliti keputihan yang terjadi pada masa kehamilan adalah hal yang fisiologis terjadi pada masa kehamilan dikarenakan perubahan hormone dalam tubuh selama masa kehamilan. Pada penelitian ini perawatan keputihan pada responden didominasi oleh katagori kurang baik hal ini dikarenakan banyaknya responden yang menganggap bahwah halt ersebut adalah normal ${ }^{17}$.

Menurut penelitian Novita, mengatakan bahwa adanya hubungan antara sikap ibu hamil dalam melakukan perawatan keputihan yang dialami, hal ini ditunjukkan dengan sebagian besar ibu hamil belum mengetahui tentang cara menangani keputihan yang baik selama hamil, hal ini sejalan dengan penelitian sebelumnya oleh Bening yaitu adanya hubungan antara sikap yang buruk 
ibu hamil yang mengalami keputihan akan berdampak atau berlanjut kedalam keputihan yang patologi, sehingga terdapat hubungan antara sikap hygiene dengan kejadian keputihan ${ }^{13}$.

\section{Hubungan Pengetahuan dan Sikap IbuHamil dalam PerawatanKeputihan di Puskesmas Gedong Tataan.}

Hasil uji statistik chi square hubungan pengetahuan dan sikap ibu hamil dengan perawatan keputihan di Puskesmas Gedung Tataan didapat nilai $p$ value $=0,004<\alpha 0,05$ berarti ada hubungan tingkat pengetahuan ibu hamil dengan perawatan keputihan di puskesmas Gedong Tataan tahun 2019. Dari hasil analisis diperoleh pula nilai $\mathrm{OR}=8,75$ yang berarti responden yang berpengetahuan baik mempunyai peluang 8,75 kali lebih besar untuk melakukan perawatan keputihan dengan baik dibandingkan responden yang berpengetahuan kurangbaik

Pengetahuan dapat berhubungan dengan hal luas seperti sebuah teori dan hal yang sempit seperti fakta ${ }^{10}$. Pengetahuan tentang perawatan keputihan pada masa kehamilan dapat memunculkan sikap yang positif, hal ini sejalan dengan penelitian yang dilakukan oleh Intan yang mengatakan bahwa adanya hubungan antara pengetahuan yang baik terhadap kejadian keputihan yang dialami oleh wanita.

Keputihan yang disebabkan oleh infeksi biasanya disertai gatal dengan rasa gatal di dalam vagina dan disekitar bibir vagina bagian luar, kerap pula disertai bau busuk. Keputihan biasanya terjadi selama kehamilan, menjelang atau sesudah menstruasi dan pada masa ovulasi atau masa subur $^{2}$ Hasil penelitian ini sejalan dengan Fitrianingsih 2012, yang berjudul hubungan tingkat pengetahuan, sikap dan perilaku pemeliharaan organ reproduksi dengan risiko kejadian keputihan pada siswi kelas X SMA. Hasil uji Chi Square diperoleh nilai statistik $\mathrm{p}=0,000(\leq 0,05)$. Berarti Ha diterima, sehingga ada hubungan antara pengetahuan tentang pemeliharaan kesehatan reproduksi ${ }^{17}$. Menurut peneliti perilaku seseorang dipengaruhi oleh banyak faktor diantaranya pengetahuan, pendidikan, lingkungan dan keterpaparan informasi. Pada penelitian ini pengetahuan ibu di dominasi dengan katagori baik yaitu $73,2 \%$ sedangkan perawatan keputihan pada katagori buruk yaitu $63,4 \%$, hal ini dikarenakan ibu hamil yang memahami tentang keputihan menganggap itu adalah hal yang normal, selain itu batasan gestasi pada ibu hamil juga mempengaruhi perawatan keputihan. Karena seiring berjalannya usia kehamilan maka kadar hormon estrogen dan progesterone akan terus meningkat hal tersebut menyebabkan angka kejadian keputihan juga semakin meningkat. Penelitian yang dilakukan oleh Sartje, mengatakan bahwa sebagian besar ibu yang memiliki pengetahuan dan sikap yang baik 
akan melakukan perawatan keputihan yang dialami selama kehamilan dengan baik.

Selain dari sikap dan pengetahuan salah satu faktor yang mampu mempengaruhi seseorang terhadap perawatan keputihan pada ibu hamil adalah budaya. Pengaruh kebudayaan juga dapat memengaruhi terjadinya sikap, karena suatu budaya yang terjadi dalam suatu daerah dapat melakukan suatu tindakan yang tidak logis, sehingga orang dapat menanamkan sikap yang negatif maupun positif. Seperti cara membersihkan alat kewanitaan menggunakan air rebusan daun sirih dan meminum jamu dapat mengobati keputihan. Sesuai dengan teori yang dikemukakan oleh Azwar (2015), komponen kognitif merupakan apa yang dipercayai oleh setiap individu pemilik sikap mengenai apa yang berlaku atau yang benar bagi objek sikap ${ }^{15}$.

Sesuai dengan teori yang dikemukakan oleh Azwar komponen kognitif merupakan apa yang dipercayai oleh setiap individu pemilik sikap mengenai apa yang berlaku atau yang benar bagi objek sikap. Menanggulangi keputihan pada ibu hamil maka harus diperlukan sikap dan perilaku yang baik, menurut Syaifuddin, bahwa sikap merupakan kesiapan mental yaitu suatu proses yang berlangsung dalam diri seseorang, bersama dengan pengalaman individual masingmasing, mengarahkan dan menentukan respon terhadap berbagai objek dan situasi. Dengan perawatan keputihan yang kurang baik maka akan meyebabkan kondisi yang membuat ibu hamil tersebutpun malu terutama dalam hal bersosialisasi dengan orang lain maupun dalam hal berhubungan badan dengan pasangannya ${ }^{3}$.

\section{KESIMPULAN}

Dalam penelitian kami menyimpulkan, tingkat pengetahuan dan sikap ibu hamil berhubungan dengan perawatan keputihan di puskesmas Gedong Tataan tahun 2019 ( $p$ value :0,004, OR: 8,75). Disarankan untuk meningkatkan pendidikan kesehatan tentang perawatan keputihan pada masa kehamilan agar ibu hamil.

\section{DAFTAR PUSTAKA}

1. Walyani E. Perawatan Kehamilan \& Menyusui Anak Pertama. Pustaka Baru Press; 2015.

2. Anolis. 17 Penyakit Wanita Yang Paling Mematikan. Buana Pustaka; 2011.

3. Syaifuddin. Ilmu Kebidanan. Yayasan Bina Pustaka Sarwono Prawiroharjo; 2017.

4. Dagasou E. D. Gambaran Tingkat Pengetahuan Ibu Tentang Keputihan Di Poliklinik Obstetri/Ginekologi Rsu. Pancaran Kasih Gmim Manado. Published Online 2014.

5. Irmawati. Tanya Jawab Lengkap Kehamilan Bermasalah. Laksana; 2016.

6. Kusuma A. Faktor- Faktor Yang Melatarbelakangi Kejadian Abortus Imminens Pada Ibu Hamil Di Sukadana Kabupaten Kayong Utara. 
2016.

7. Marhaeni Ga. Keputihan Pada Wanita Gusti. $J$ Skala Husada. 2016;13(1):30-38.

Doi:10.1007/S11038-006-9134-2

8. Notoatmodjo S. Ilmu Perilaku Kesehatan. Rineka Cipta; 2015.

9. Zalni Ri. Hubungan Pengetahuan Dan Sikap Remaja Putri Tentang Vulva Hygiene Dengan Tindakan Pencegahan Keputihan. Ensiklopedia J Hub. 2018;1(1):147-152.

10. Musdhalifah. Gambaran Pengetahuan Ibu Hamil Tentang Keputihan Di Rumah Sakit Ibu Dan Anak Siti Fatimah Makasar. Published Online 2011.

11. Sukamto Nr, Yahya Yf, Handayani D, Argentina F, Liberty Ia. Hubungan Pengetahuan, Sikap, Dan Perilaku Perawatan Vagina Terhadap Kejadian Keputihan Patologis Pada Mahasiswi Program Studi Pendidikan Dokter Fakultas Kedokteran Universitas Sriwijaya. Maj Kedokt Sriwij. 2018;50(4):213-221.

Doi:10.36706/Mks.V50i4.8571

12. Natika N. Gambaran Sikap Ibu Hamil Dalam Menangani Keputihan Di Puskesmas Cangkringan Sleman Yogyakarta. Published Online 2016.
13. Usman Bp. Hubungan Perilaku Hygiene Organ Genetalia Eksterna Dengan Jenis Keputihan Pada Ibu Hamil Usia Gestasi 11-24 Minggu. Published Online 2013.

14. Ari D, Yanti M, Sulistianingsih A, Karani E. Upaya Meningkatkan Kebersihan Genetalia Remaja Putri Untuk Mencegah Kejadian Flour Albus Di Sma Dalam Muhammadiyah Kalirejo. 2016;Xiv(2).

15. Azwar S. Sikap Manusia Teori Dan Pengukurannya. Pustaka Pelajar; 2015.

16. Azizah N, Widiawati I. Latar Belakang Diindonesia Wanita Keputihan Sekitar Keputihan Juga Dialami Oleh Wanita Yang Belum Kawin Atau Remaja Puteri Berumur Karena Mengalami Negara Sesuai Dengan Data Skrri ( 2007 ), Dalam Bulan Terakhir Indonesia Adalah Daerah Yang Beriklim Tropis. 2015;6(1):57-78.

17. Fitrianingsih Hr. Pemeliharaan Organ Reproduksi Dengan Risiko Kejadian Keputihan Pada Siswi Kelas X Sma Negeri 1 Wonosari Kabupaten Klaten Skripsi Ini Disusun Untuk Memenuhi Salah Satu Syarat Memperoleh Ijazah S-1 Kesehatan Masyarakat Disusun Oleh Program Studi Kesehatan M. Univ Muhammadiyah Surakarta 2012. Published Online 2012. 